\title{
Umbraulva yunseulla sp. nov. (Ulvaceae, Chlorophyta) from a subtidal habitat of Jeju Island, Korea
}

\author{
Hyung Woo Lee ${ }^{1}$, Eun Hee Bae ${ }^{2}$ and Myung Sook Kim ${ }^{1,3, *}$ \\ ${ }^{1}$ Research Institute for Basic Sciences, Jeju National University, Jeju 63243, Korea \\ ${ }^{2}$ Microorganism Resources Division, National Institute of Biological Resources, Incheon 22689, Korea \\ ${ }^{3}$ Department of Biology, Jeju National University, Jeju 63243, Korea
}

\begin{abstract}
Specimens of Umbraulva with greenish iridescent were collected in the subtidal zone of Jeju Island, Korea. To investigate these collections, plastid $r b c \mathrm{~L}$ and tufA sequencing of six greenish iridescent specimens, including four $\mathrm{Um}$ braulva japonica, were analyzed. Phylogenetic analysis of a concatenated multigene alignment found that the greenish iridescent specimens belonged to a yet undescribed taxon in the genus Umbraulva. We herein propose the name Um. yunseulla sp. nov. for this specimens. Juveniles of Um. yunseulla sp. nov. resemble the generitype Um. japonica in appearance, showing globular to subglobular and funnel-shaped habits, but the blades of this new species are not split longitudinally like those of Um. japonica. Although the multigene phylogenetic tree showed the polyphyletic clade of Umbraulva with respect to the genus Ryuguphycus, Um. yunseulla sp. nov. formed a clade with Um. japonica and Um. amamiensis by weak bootstrap support. These findings, Um. yunseulla sp. nov., highlight the importance of studying the biodiversity of subtidal habitats from Jeju Island, Korea and further emphasize the need for investigations of macroalgae in the mesophotic zone around the Korean peninsula.
\end{abstract}

Key Words: biodiversity; greenish iridescent; phylogeny; rbcL; taxonomy; tufA; Umbraulva yunseulla sp. nov.

\section{INTRODUCTION}

The genus Umbraulva was segregated from the genus Ulva by Bae and Lee (2001) and includes three species previously described as U. amaniensis Tanaka (type locality: Amami-Oshima, Japan), U. japonica (Holmes) Papenfuss (type locality: Enoshima, Japan), and U. olivascens Dangeard (type locality: Roscoff, France). Umbraul$v a$ is distinguished from Ulva Linnaeus by its distinct olive-green blade, subtidal habitat, and the presence of the pigment siphonaxanthin (Bae and Lee 2001), which pigment can grow in deeper waters because they absorb green light in the 540-nm range (Yokohama 1981). Umbraulva kuaweuweu H. L. Spalding \& A. R. Sherwood and Um. kaloakulau H. L. Spalding \& A. R. Sherwood were described as new species from specimens collected at depths of 80-125 $\mathrm{m}$ in mesophotic ecosystems of the Hawaiian Archipelago based on vegetative morphology and molecular phylogenetic analyses of the internal transcribed spacer (ITS) region, ribulose-1,5-biphosphate carboxylase large subunit $(r b c \mathrm{~L})$, and elongation factor $\mathrm{Tu}$ (tufA) genes (Spalding et al. 2016). Although it was known that Umbraulva includes five species taxonomically (Guiry and Guiry 2020), the new genus Ryuguphycus H. Kawai, T. Hanyuda \& T. Kitayama, which includes $R$. kuaweuweu (formerly Um. kuaweuweu) as the generi-
(9) $\$$ This is an Open Access article distributed under the terms of the Creative Commons Attribution Non-Commercial License (http://creativecommons.org/licenses/by-nc/3.0/) which permits unrestricted non-commercial use, distribution, and reproduction in any medium, provided the original work is properly cited.
Received September 4, 2020, Accepted December 3, 2020

* Corresponding Author

E-mail: myungskim@jejunu.ac.kr

Tel: +82-64-754-3523, Fax: +82-64-756-3520 
type, was recently separated from the genus Umbraulva based on its distinctive morphology, life history, carotenoid composition, and molecular phylogeny (Kawai et al. 2020).

Two Umbraulva species, Um. amamiensis and Um. japonica, have been reported from subtidal habitats in Korea (National Institute of Biological Resources 2019); however, it is very difficult to identify species correctly based on a few traditional morpho-anatomical characteristics such as blade shape and thickness, presence / absence of microscopic marginal denticulation, and rhizoidal filament type (Spalding et al. 2016, Kawai et al. 2020). The plastid markers $r b c L$ and tufA have been used to delimit species boundaries in Umbraulva, including several new undescribed specimens (Heesch et al. 2009, Kirkendale et al. 2013). Therefore, it is necessary to study the systematics of this genus using molecular phylogenetic information and/or monitor the occurrence of invasive species in subtidal areas. During subtidal zone surveys around Jeju Island, Korea, we discovered a novel Umbraulva species; this finding is supported by molecular analyses and morphological observations. The objectives of this study were to determine the taxonomic position of this new species, assess its genetic differences from related taxa, and discuss the phylogenetic relationships of Umbraulva based on the plastid $r b c \mathrm{~L}$ and tufA genes.

\section{MATERIALS AND METHODS}

Using scuba gear, we collected six specimens of a new Umbraulva candidate and four of Um. japonica from depths of 8-15 $\mathrm{m}$ in subtidal areas around four annexed islets (Hyeongjeseom, Munseom, Seopseom, and Udo) of Jeju Island, Korea. The fresh samples were photographed using an Olympus TG-4 waterproof digital camera (Olympus, Tokyo, Japan). Thallus fragments of each specimen were dried for molecular analyses using silica gel. Prior to describing morphological characters, the samples were preserved in $5 \%$ formalin in seawater and sectioned using a bench-top freezing microtome (NK-101-II; Nippon Optical Works Co., Ltd., Tokyo, Japan). Sectioned materials were stained with $1 \%$ aniline blue acidified with $1 \% \mathrm{HCl}$ after bleaching under sunlight. Sections were mounted in $35 \%$ corn syrup and photographed under a microscope (BX43; Olympus) using an EOS 600D digital camera (Canon, Tokyo, Japan). Digitized images were edited for clarity using Adobe Photoshop software (ver. 6.1; Adobe Systems Inc., San Jose, CA, USA). Pressed herbarium specimens were deposited as voucher specimens in the herbaria of Jeju National University (JNUB) and the National Institute of Biological Resources (KB), Incheon, Korea.

Total genomic DNA of two Umbraulva species (Table 1) was extracted following the protocol of the LaboPass Tissue Genomic DNA Isolation Kit Mini (Cosmo Genetech, Seoul, Korea). All polymerase chain reaction (PCR) processes were performed using AccuPower PCR Premix (Bioneer, Daejeon, Korea), following the manufacturer's protocol. We amplified and sequenced the plastid genes $r b c \mathrm{~L}$ and tufA and analyzed nuclear 18S rRNA from an unidentified Umbraulva species. In the present study, the primer combinations for $r b c \mathrm{~L}$, tufA, and 18S rRNA5P were GrbcLFi (Saunders and Kucera 2010) or RH1 (Manhart 1994) / 1385R (Manhart 1994), tufGF4 / tufGR

Table 1. Sequence information of Umbraulva yunseulla sp. nov. and Umbraulva japonica analyzed newly in this study

\begin{tabular}{|c|c|c|c|c|c|}
\hline \multirow{2}{*}{$\begin{array}{c}\text { Species } \\
\text { Voucher No. }\end{array}$} & \multirow{2}{*}{ Date } & \multirow{2}{*}{ Site } & \multicolumn{3}{|c|}{ GenBank accession No. } \\
\hline & & & $r b c \mathrm{~L}$ & tufA & 18S rRNA \\
\hline \multicolumn{6}{|l|}{ Umbraulva yunseulla } \\
\hline MSK-GA00064 & Jan 30, 2013 & Munseom, Jeju, Korea & - & МТ978114 & MT978101 \\
\hline MSK-GA00068 & Jan 30, 2013 & Munseom, Jeju, Korea & - & MT978115 & - \\
\hline MSK-GA00069 & Jan 30, 2013 & Munseom, Jeju, Korea & MT978109 & MT978116 & - \\
\hline MSK-GA00070 & Jan 30, 2013 & Munseom, Jeju, Korea & - & MT978117 & - \\
\hline MSK-GA00071 & Jan 30, 2013 & Munseom, Jeju, Korea & МТ978110 & МТ978118 & - \\
\hline MSK-GA00072 & Jan 30, 2013 & Munseom, Jeju, Korea & - & MT978119 & - \\
\hline \multicolumn{6}{|c|}{ Umbraulva japonica (Holmes) } \\
\hline \multicolumn{6}{|c|}{ Bae \& I. K. Lee } \\
\hline MSK-JDWT24 & Dec 27, 2017 & Jongdal, Jeju, Korea & МТ978123 & МТ978107 & - \\
\hline MSK-JDWT25 & Dec 27, 2017 & Jongdal, Jeju, Korea & МT978124 & МТ978108 & - \\
\hline MSK-SYWT98 & $\operatorname{Jan} 2,2018$ & Shinyang, Jeju, Korea & MT978125 & MT978105 & - \\
\hline MSK-SYWT99 & Jan 2, 2018 & Shinyang, Jeju, Korea & MT978126 & MT978106 & - \\
\hline
\end{tabular}


(Saunders and Kucera 2010), and SSU-A (Medlin et al. 1988) / SSU_inR (Manhart 1994), respectively. The PCR amplification procedure followed that of Saunders and Kucera (2010). All successfully amplified PCR products were purified using an AccuPrep PCR Purification Kit (Bioneer) and sequenced by Macrogen (Seoul, Korea) using forward and reverse primers. Additional $r b c \mathrm{~L}$ and tufA sequences for the phylogenetic analysis were selected from GenBank (Supplementary Table S1). The $r b c \mathrm{~L}$ and tufA datasets were aligned visually using the BioEdit software (Hall 1999) after editing the Umbraulva sequences obtained in this study using Chromas ver. 1.45 software (Technelysium Pty Ltd., South Brisbane, Australia). Variations in the $r b c \mathrm{~L}$ and $t u f \mathrm{~A}$ sequences were assessed based on uncorrected pairwise genetic distances (p-distance) using MEGA 5.1 software (Tamura et al. 2011) and a neighbor-joining algorithm dependent on the Kimura two-parameter distance method. To determine the taxonomic positions of our Umbraulva specimens (Table 1), each $r b c \mathrm{~L}$ and tufA phylogeny was run using a maximum-likelihood (ML) algorithm with RAxML software (Stamatakis 2006) and the GTR $+\Gamma+$ I model with 1,000 bootstrap (BS) replicates from each sequence dataset for our Umbraulva specimens (Table 1) and related ulvacean taxa (Supplementary Table S1), including Ulvaria obscura (rbcL, HQ603436 and HQ603651; tufA, HQ610415) as an outgroup. We constructed a combined phylogenetic tree inferred from the $r b c \mathrm{~L}$, tufA, 18S rRNA, 28S rRNA, and ITS sequence datasets (Supplementary Table S1) to delimit the generic boundaries within Ulvaceae. This concatenated phylogenetic tree was constructed using the ML method in RAxML software and expressed using FigTree ver. 1.4.0 software (Rambaut 2012).

\section{RESULTS}

We analyzed a set of $53 \mathrm{rbcL}$ gene sequences including two new Umbraulva sp. specimens (MT978109MT978110; 741-745 bp) and four Um. japonica ones (MT978123-MT978126; 1,263-1,273 bp). Among all sites $r b c \mathrm{~L}, 185$ sites (14.5\%) were variable and 137 sites $(10.8 \%)$ were parsimoniously informative. In tufA analysis, a set of 40 tufA gene sequences were analyzed including six new Umbraulva sp. specimens (MT978114-MT978119; 804-859 bp) and four Um. japonica ones (MT978107MT978106; 848-866 bp). Variable and parsimoniously informative sites were 327 sites (37.8\%) and 169 (19.7\%), respectively. In addition, a $18 \mathrm{~S}$ rRNA-5P sequence were obtained from a new Umbraulva sp. specimen
(MT978101; $530 \mathrm{bp).} \mathrm{Phylogenetic} \mathrm{analysis} \mathrm{of} \mathrm{the} \mathrm{plas-}$ tid $r b c \mathrm{~L}$ and tufA sequences showed that the six new Umbraulva sp. specimens from Jeju Island were separated from other species within Umbraulva clade in a fully supported clade (BS, 100), with sister to Um. kaloakulau from Hawaii, USA (Figs $1 \& 2$ ). The $r b c$ L phylogeny showed that the novel Umbraulva sp. had diverged from the Um. japonica clade from Korea (MT978123, MT978124, MT978125, and MT978126) including the generitype from Japan (AB097612 and LC507134), as well as Um. amamiensis (AB097614 and LC 507131), with an interspecific variation of $2.6-3.3 \%$ and $2.6 \%$, respectively (Fig. 1). Higher interspecific divergence among $\mathrm{Um}$ braulva species was observed in the tufA phylogenentic analysis compared to the $r b c \mathrm{~L}$ results. The tufA interspecific variation values for the novel Umbraulva sp. were $1.6 \%$ vs. Um. kaloakulau, $6.6-7.0 \%$ vs. Um. japonica, and $4.2 \%$ vs. Um. amamiensis.

Although the genus Ulva is monophyletic based on the $r b c \mathrm{~L}$ and tufA genes ML phylogeny, Umbraulva clade was not monophyletic because of the genus Ryuguphycus embedded within this clade. In addition, the concatenated ML phylogeny showed that Umbraulva consists of two clades, one containing Um. japonica, Um. amamiensis, Um. kaloakulau, and the novel Umbraulva sp. (Fig. 3) with weak ML support (BS, 69\%), and the other consisting of Um. dangeardii from Ireland and France (EU484411 and LC507133, respectively), Umbraulva sp. specimens from New Zealand (EF110497, EF110504, and EF110288) and Australia (JN029249, rbcL, and JN029348) (Supplementary Table S1), and Ryuguphycus with no support (Fig. 3). Although the clade of Umbraulva is unstable on the basis of the molecular evidence, we propose a new species of Umbraulva, hereby named Um. yunseulla $\mathrm{H}$. W. Lee, E. H. Bae \& M. S. Kim sp. nov.

\section{Umbraulva yunseulla H. W. Lee, E. H. Bae \& M. S. Kim sp. nov. (Fig. 4A-L)}

Holotype. MSK-GA00069 (Fig. 4B), vegetative, Munseom (annexed islet), Jeju Island, Korea, Jan 30, 2013, deposited in the JNUB herbarium: GenBank accession No. MT978109, rbcL; MT978116, tufA.

Isotypes. MSK-GA00068, MSK-GA00071, vegetative, Munseom (annexed islet), Jeju Island, Korea, Jan 30, 2013 (deposited in JNUB). MSK-GA00064, MSK-GA00070 (Fig. 4C), MSK-GA00072, vegetative, Munseom, Jeju Island, Korea, Jan 30, 2013 (deposited in KB).

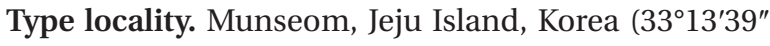
N, 126 33'57" E). 


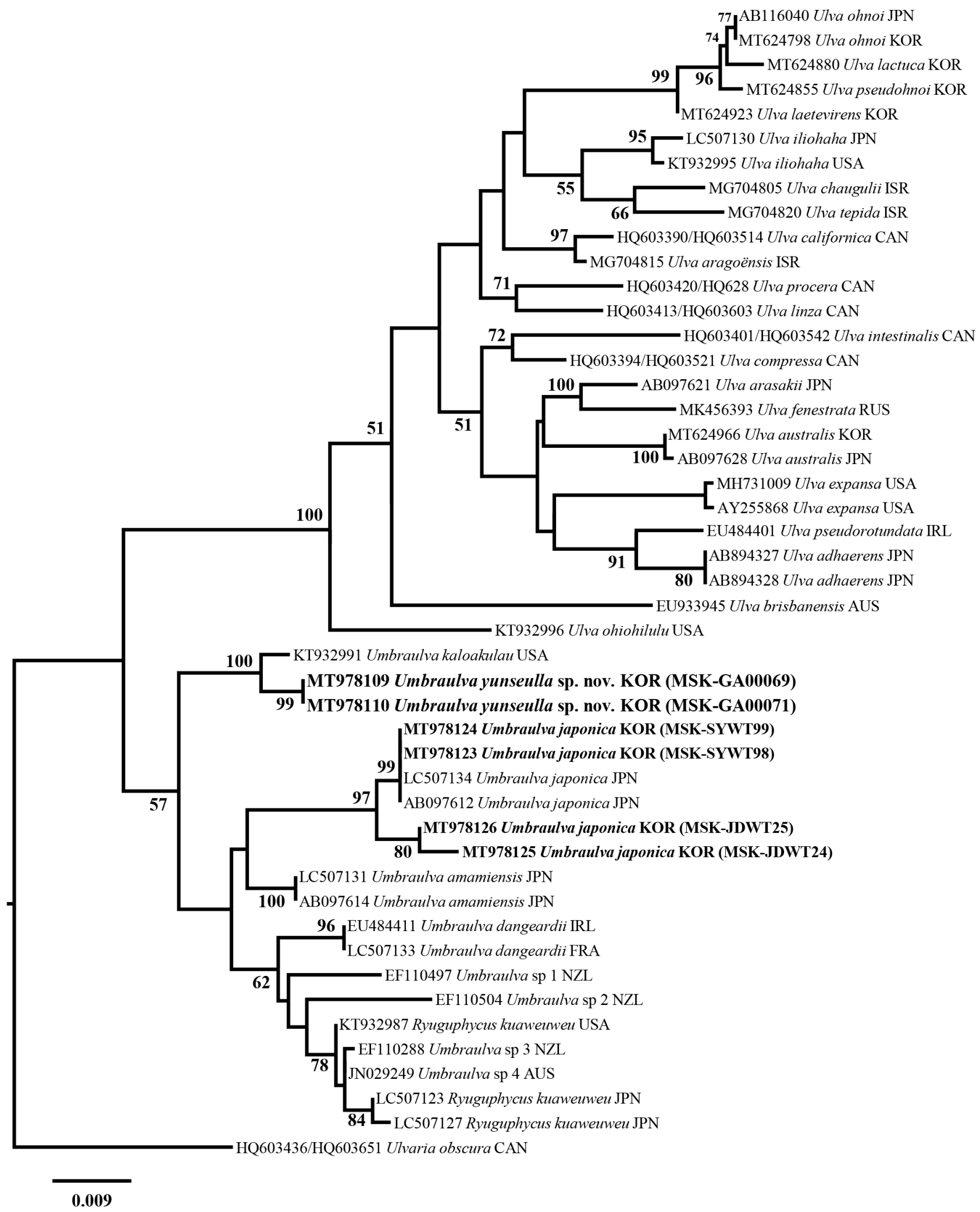

Fig. 1. Maximum likelihood phylogenetic tree inferred from the plastid $r b c L$ of Ulvaceae species with Umbraulva yunseulla sp. nov. Numbers on the branches indicate the bootstrap values with only $\geq 50 \%$. Sequences produced in this study are marked in bold font. Branch lengths are proportional to substitution rate. 


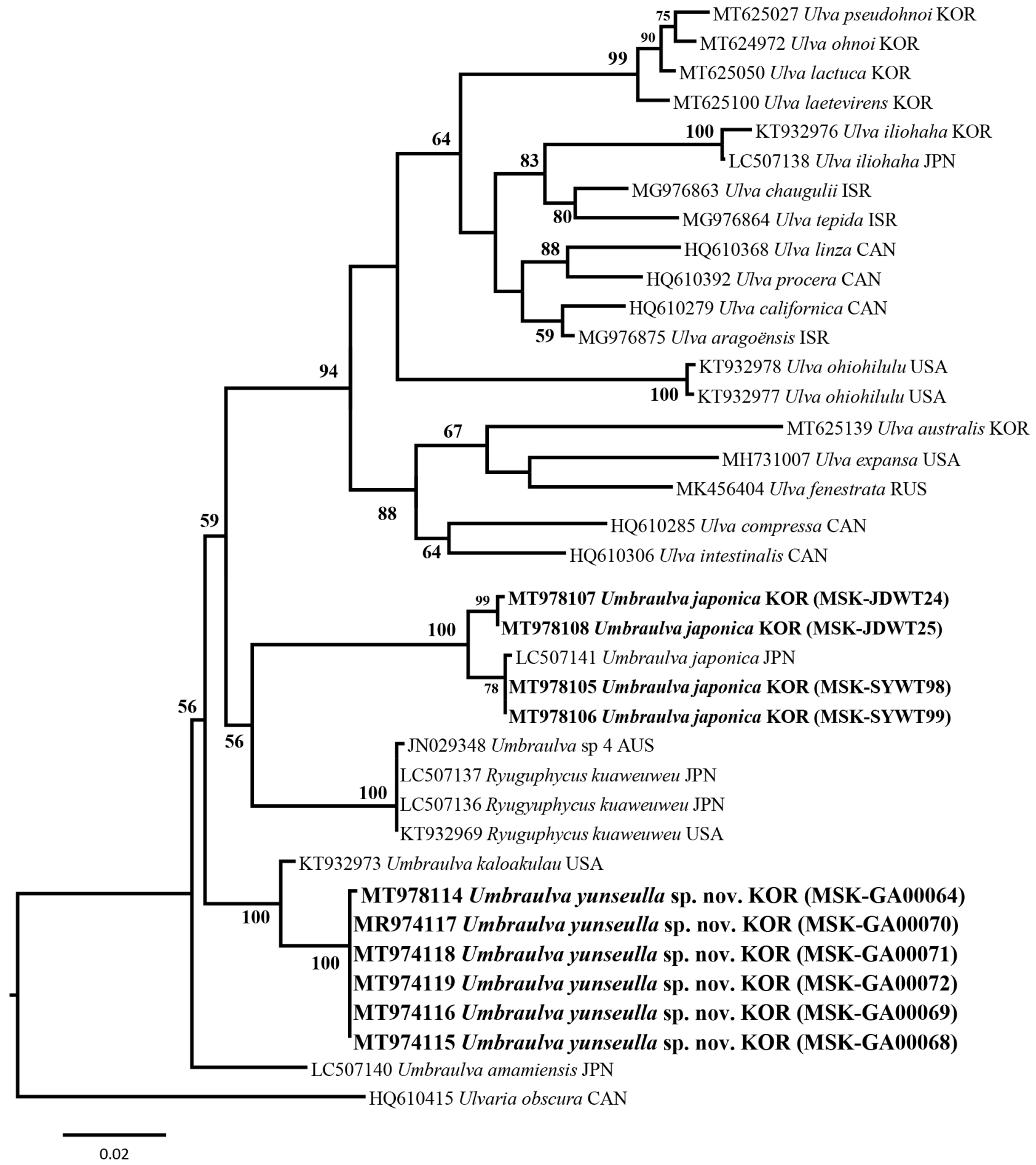

Fig. 2. Phylogenetic tree inferred from the plastid tufA of Umbraulva yunseulla sp. nov. constructed by maximum likelihood analysis. Numbers on the branches indicate the bootstrap values with only $\geq 50 \%$. Sequences produced in this study are marked in bold font. Branch lengths are proportional to substitution rate. 


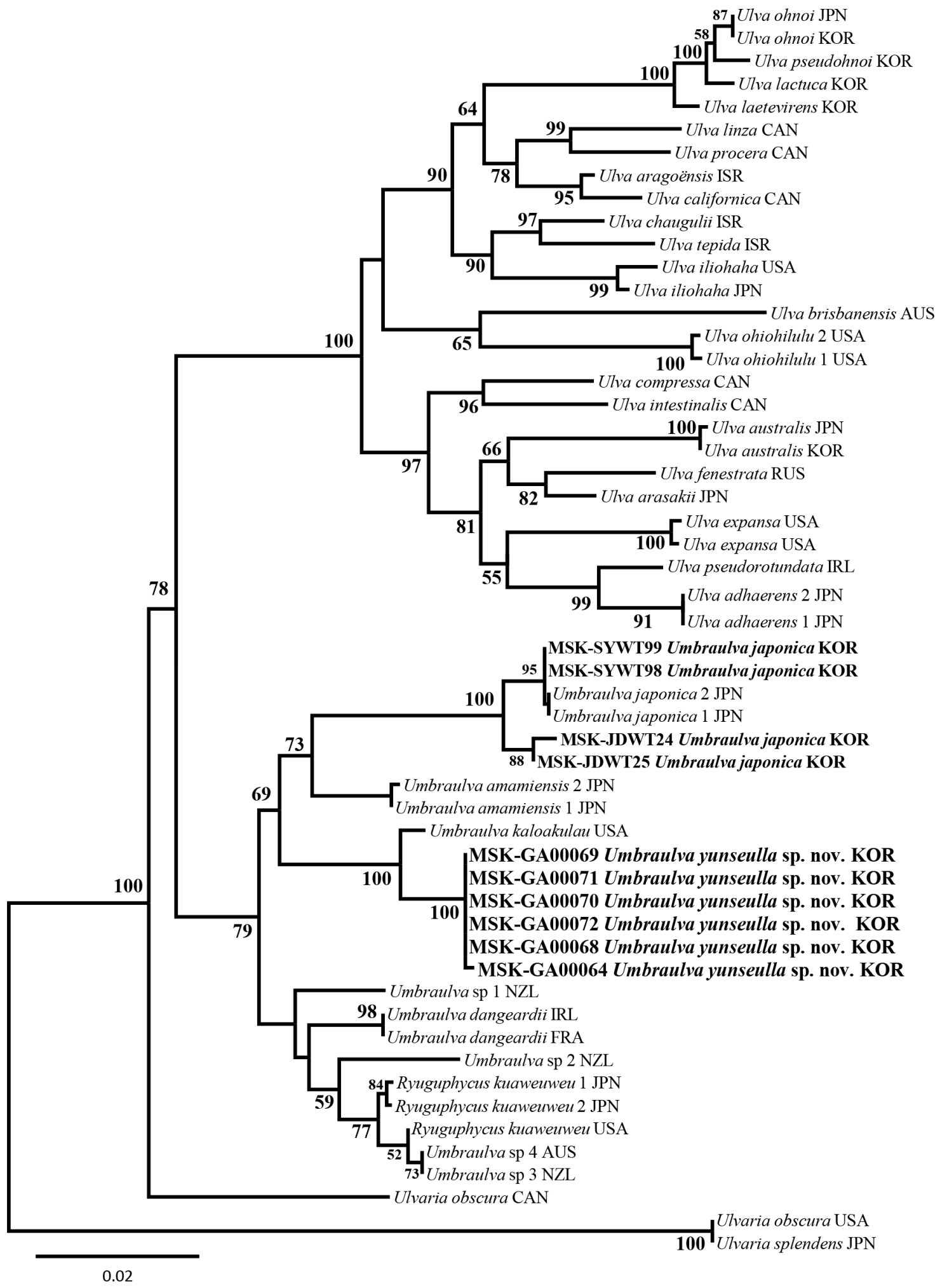

Fig. 3. Maximum likelihood phylogeny of Ulvaceae inferred from five gene regions, rbcL, tufA, 18S rRNA, 28S rRNA, and ITS (total 5,634 bp). Numbers on the branches indicate the bootstrap values with only $\geq 50 \%$. The GenBank accession numbers of each sequence data set are shown in Supplementary Table S1. Specimens analyzed in this study are marked in bold font. Branch lengths are proportional to substitution rate. 
Etymology. The specific epithet, yunseulla, is derived from the Korean traditional noun yunseul, meaning "calm wave glittering with sunshine or moonlight" in reference to the greenish iridescence observed on the underwater thallus surface.

\section{Korean name. 윤슬초록갈파래 (국명신칭).}

Habitat. Attached to hard substrates such as rocks, shells, or nongeniculate corallines in the subtidal zone (generally 8-15 $\mathrm{m}$ deep).

Distribution. Jeju Island, Korea.

Specimens examined. MSK-GA00064, MSK-GA00068, MSK-GA00069, MSK-GA00070, MSK-GA00071, MSKGA00072, Jan 30, 2013, Munseom, Jeju Island, Korea; MSK150802-06, Aug 2, 2015, Sagye, Jeju Island, Korea; MSKL160414-14, MSKL160414-15, MSKL160414-16, MSKL160414-17, Apr 14, 2016, Munseom, Jeju Island, Korea; MSKL160419-03, MSKL160419-12, MSKL160419-13, MSKL160419-14, Apr 16, 2016, Munseom, Jeju Island, Korea; MSKL160419-19, MSKL160419-22, Apr 19, 2016, Seopseom (annexed islet), Jeju Island, Korea; MSKL160520-10, May 20, 2016, Munseom, Jeju Island, Korea; MSKL16052816, MSK160528-17, May 28, 2016, U-do (annexed islet), Jeju Island, Korea (deposited in JNUB).

DNA sequence data. rbcL: MSK-GA00069 (MT978109), MSK-GA00071 (MT978110). tufA: MSK-GA00064 (MT978114), MSK-GA00068 (MT978115), MSK-GA00069 (MT978116), MSK-GA00070 (MT978117), MSK-GA00071 (MT978118), MSK-GA00072 (MT978119). 18SrRNA: MSK-GA00064 (MT978101).

Habit and morphology. Umbraulva yunseulla sp. nov. has a foliose (Fig. 4B \& C) and distromatic (Fig. 4H \& I) thallus with slightly ruffled to curled margins (Fig. 4B \& C). Greenish iridescence derived from the natural habitat glitters on the surface radially from the lower part or at the margin of the thallus (Fig. 4A). Thallus green to dark green (Fig. 4B \& C). Thallus entirely globular to subglobular and funnel-shaped, growing dorsiventrally decumbent when young to erect when mature (Fig. 4A), $5-7 \mathrm{~cm}$ wide and $4-5 \mathrm{~cm}$ high, to a maximum of $10 \mathrm{~cm}$ (Fig. 4B $\& \mathrm{C})$. Thallus apex rounded to slightly emarginated, base cordate to lobate (Fig. 4B \& C). Thallus attached by a distinct discoid holdfast without a stipe (Fig. 4B \& C) and generally composed of a single or 2-3 (5) blades (Fig. 4B \& C). Distromatic thallus is composed of entirely cuboidal to polygonal cells, some subspherical in the upper part of the blade in surface view, 11-26 $\mu \mathrm{m}$ long by 9-16 $\mu \mathrm{m}$ wide (Fig. 4D). In the center of the blade, cells are subspherical, cuboidal to polygonal, 15-35 $\mu \mathrm{m}$ long by 9-18 $\mu \mathrm{m}$ wide, and are larger and more numerous than in the upper blade (Fig. 4E). At the base, subspherical, cuboi- dal and polygonal cells, 18-55 $\mu \mathrm{m}$ long by 9-26 $\mu \mathrm{m}$ wide, are intermixed (Fig. 4F). Pale cells are greatly expanded, and darker cells are filled with cytoplasm in a compact arrangement (Fig. 4F). Each cell contains 1-2 pyrenoids (Fig. 4E), up to 4 per cell. Cell arrangement throughout the thallus irregular (Fig. 4D-F). Thallus margin entire, plain, and rounded, without microscopic protuberances (Fig. 4G). In transverse section, cell shape is cuboidal throughout the entire blade (Fig. $4 \mathrm{H}-\mathrm{J}$ ). Cell size in transverse section is taller and wider toward basal part, 26-32 $\mu \mathrm{m}$ tall by 11-13 $\mu \mathrm{m}$ wide in upper, 23-28 $\mu \mathrm{m}$ tall by $13-17 \mu \mathrm{m}$ wide in middle, $40-60 \mu \mathrm{m}$ tall by $23-37 \mu \mathrm{m}$ wide in basal, but similar throughout the thallus on both the dorsal and ventral surfaces (Fig. 4H-J). Cell thickness ranges from 50-70 $\mu \mathrm{m}$ in the upper thallus to $100-140 \mu \mathrm{m}$ in the basal portion of the blade. In transverse section, the basal portion of the blade, fine rhizoidal filaments are observed budding off from cells inward filled with cytoplasmic contents compactly, and are interwoven with longitudinal arrangement and fill between distromatic cell planes densely (Fig. 4J-L). Gametophytes were not observed.

\section{DISCUSSION}

Molecular analyses of the genus Umbraulva from subtidal areas of Jeju Island, Korea, have expanded our understanding of the phylogenetic affinity between Umbraulva and related taxa (Bae and Lee 2001). This approach has facilitated the discovery of the newly recognized species Um. yunseulla sp. nov., thus enhancing studies of macroalgal biodiversity. The plastid markers $r b c \mathrm{~L}$ and $t u f \mathrm{~A}$ were previously demonstrated to resolve new species and delimit boundaries among Umbraulva species (Heesch et al. 2009, Kirkendale et al. 2013). In this study, the morphological delimitation, such as size and thickness of thallus, size and shape of cell, and number of pyrenoids, provide less resolution to identify species definitely because morphological characteristic range is overlapped between Umbraulva species (Table 2). However, the phylogenetic analyses inferred $r b c \mathrm{~L}$ and tufA are helpful to reveal a new member of Umbraulva, Um. yunseulla sp. nov. from Jeju Island, Korea (Figs 1 \& 2), which has the smallest and a globular to sub-gulobular and funnel-shaped thallus with greenish iridescence along dorsal surface (Table 2).

Umbraulva yunseulla sp. nov. was first collected by Bae and Lee (2001) from Munseom, Jeju Island, Korea, but it was identified as Um.amamiensis, which is described as 

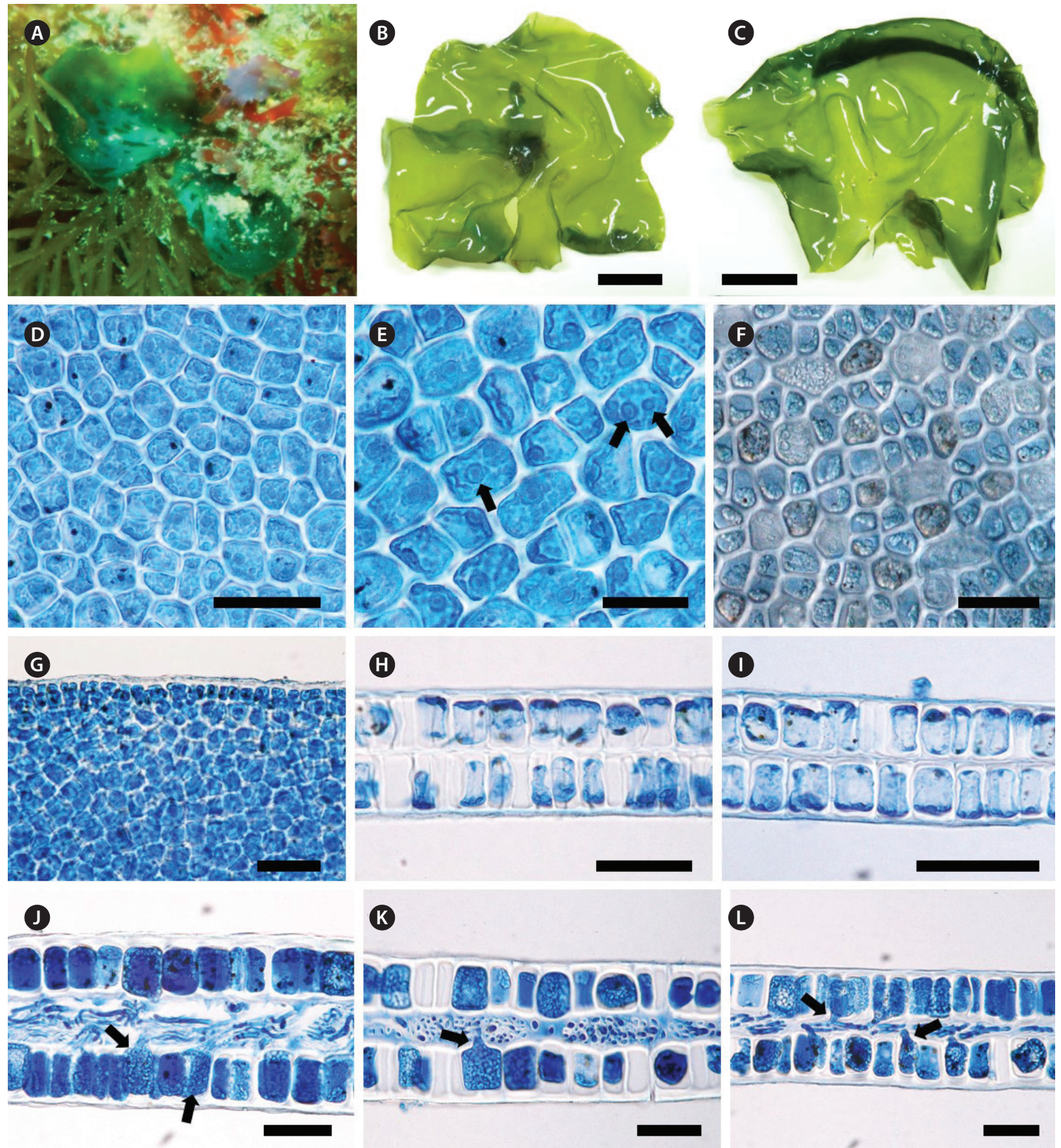

\section{《}

( )
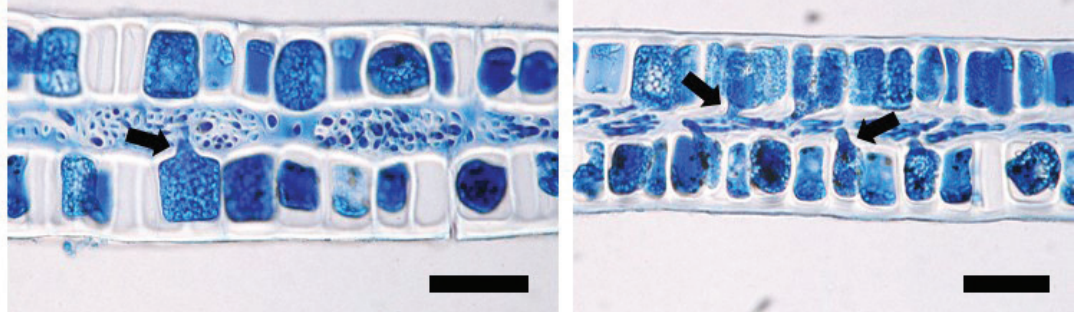

Fig. 4. Umbraulva yunseulla H. W. Lee, E. H. Bae \& M. S. Kim sp. nov. (A) Natural habit of Um. yunseulla sp. nov. from Munseom, Jeju, Apr 14, 2016, glittering with greenish iridescence. Thallus composed of two globular blades having ruffled margins. (B) MSK-GA00069, the holotype specimen, from Munseom, Jeju, Jan 30, 2013. Dorsiventral thallus habit composed a big cordate blade having rounded to slightly emarginate apex partially and another small subglobular blade. Both blades having slightly ruffled margin with curled parts. (C) MSK-GA00070, from Munseom, Jeju, Jan 30, 2013, subglobular and dorsiventral thallus having curled margins. (D) Sub-roundish or cuboidal to polygonal cells at the surface view of upper part with irregular arrangement. (E) Sub-roundish or cuboidal to polygonal cells at the surface view of middle part with irregular arrangement. Each cell containing one to two pyrenoid (arrows). (F) Sub-roundish or cuboidal cells to polygonal at the surface view of basal part with irregular arrangement. (G) Thallus margins plain without marginal denticulations or microscopic protuberances. (H) Upper part transection of blade having solid cell shape, composed of cuboidal cells. (I) Middle part transection of blade having solid cell shape, composed of cuboidal cells. (J-L) Basal part transection of blade having solid cell shape, composed of cuboidal cells with compact and interwoven rhizoids between both distromatic arrangements. Interstitial rhizoids are originated from each cell inward. Rhizoidal filaments are originated from inner part of cells filled with cytoplasmic contents compactly (arrows). Scale bars represent: B \& C, $1 \mathrm{~cm}$; D \& F-L, $50 \mu \mathrm{m} ; \mathrm{E}, 25 \mu \mathrm{m}$. 


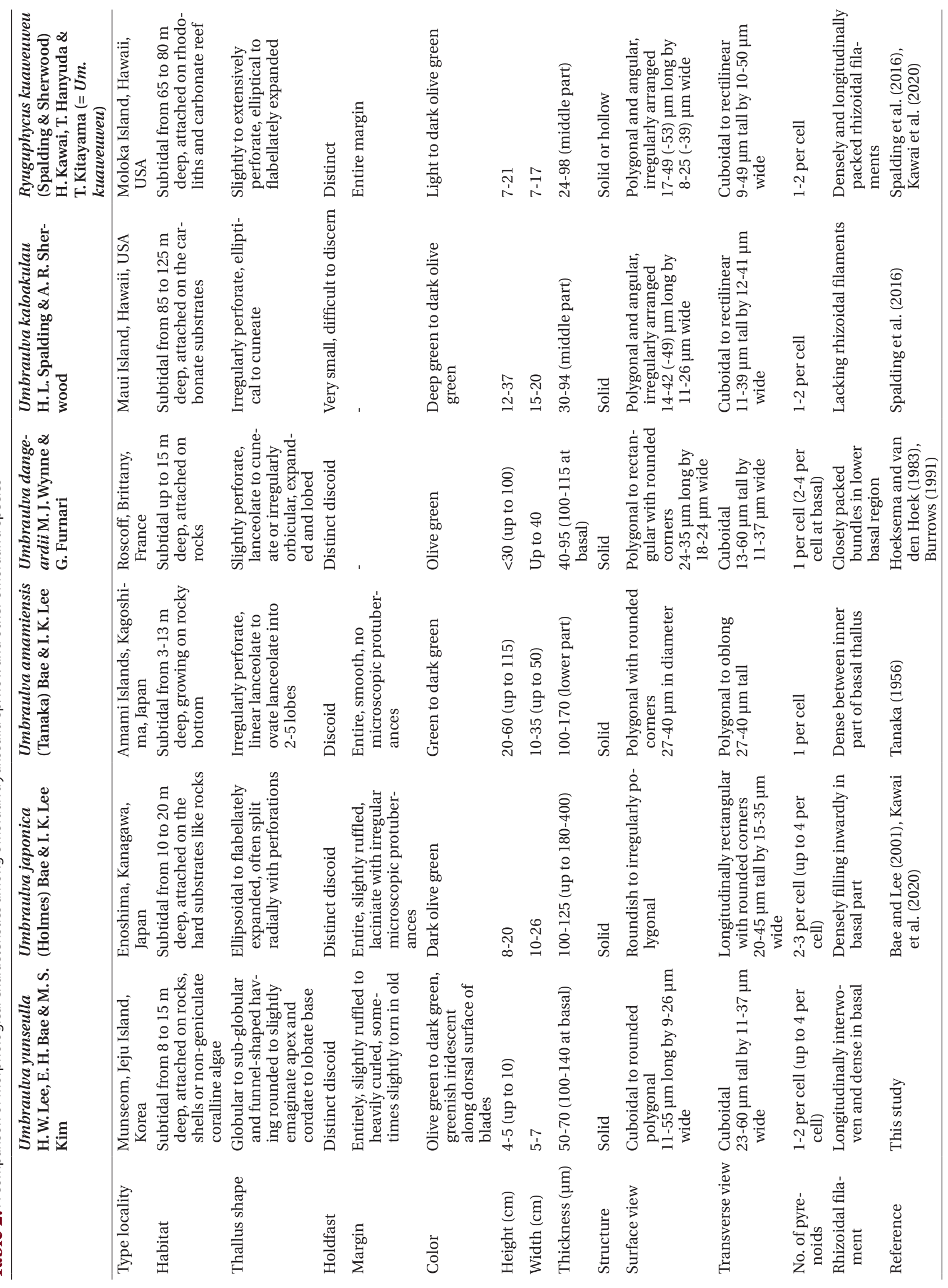


having a height of 20-60 $\mathrm{cm}$ (to $115 \mathrm{~cm}$ ) and width of 10$35 \mathrm{~cm}$ (to $55 \mathrm{~cm}$ ), with abundant perforations (Tanaka 1956). Um. yunseulla sp. nov. has much smaller thallus, ranged 5-7 cm wide and 4-5 cm high up to a maximum of $10 \mathrm{~cm}$, compared to Um. amamiensis, although these two species inhabit the similar depth range of subtidal (Table 2). The specimens of Bae and Lee (2001) were characterized by cordate or funnel-shaped thalli $5-7 \mathrm{~cm}$ in height with wavy margins and epifluorescent illumination at the surface of the blade in nature. These characteristics are identical to our specimens of Um. yunseulla sp. nov. (Table 2). On the contrary, Um. amamiensis is linear lanceolate to ovate-lanceolate with irregular perforation, and the epifluorescent illumination of Um. amamiensis specimens was undescribed (Table 2). The iridescent coloration along thallus surface is one of morphological features of Um. yunseulla sp. nov. distinguished from other Umbraulva species (Table 2). In marine macroalgae, external iridescence is caused by unique nanostructural coloration mechanisms such as intracellular iridescent bodies or multi-layered cuticle reflection (Chandler et al. 2017). Some brown and red seaweeds such as Cystoseria, Dictyota, Chondria, and Cottoniella have nanostructural coloration that produces iridescent bodies (Chandler et al. 2017). In Um. yunseulla sp. nov., greenish iridescence appears around the base or middle part of the thallus (Fig. 4A). In surface view, Um. yunseulla sp. nov. exhibits larger subspherical and expanded cells than it does cuboidal or polygonal cells; these are mainly distributed at the middle and basal parts of the thallus, and have tiny globules scattered throughout (Fig. 4E \& F). Further investigation may show that these tiny globules are iridescent bodies of Um. yunseulla sp. nov., which would provide new insight into the mechanism by which iridescent marine macroalgal species adapt to environmental conditions such as radiation intensity and turbidity (Chandler et al. 2017).

The monophyly of Umbraulva was not well-supported by $r b c L$ and tufA phylogenetic analyses (Figs $1 \& 2$ ), which is inconsistent with a previous study of the phylogenetic relationship between Umbraulva and Ryuguphycus (Kawai et al. 2020). Because the generic boundary of Umbraulva was delimited by only weak support and the Ryuguphycus clade was supported by poor BS support in our concatenated analyses inferred from $18 \mathrm{~S}$ rRNA, 28S rRNA, ITS, $r b c$ L, and tufA (Fig. 3), the phylogenetic topology between Umbraulva and Ryuguphycus presented in this study remains uncertain. The recently established genera Umbraulva and Ryuguphycus have been subject to fewer phylogenetic analyses than Ulva, which has been examined using many molecular approaches (Kirkendale et al. 2013, Spalding et al. 2016). Future studies should attempt to discover new members of Umbraulva and Ryuguphycus to fill phylogenetic gaps and strengthen generic boundaries among these genera.

Few taxonomic studies have examined ulvacean organisms inhabiting subtidal zones of Korea, with the exception of Umbraulva species (Bae and Lee 2001). Recent studies have delimited species boundaries within the genus Codium Stackhouse, including five subtidal species, and for Palmophyllum crassum (Naccari) Rabenhorst, which inhabits deep marine areas around Jeju (Lee and Kim 2015, 2017). Many red algae species have been discovered in the subtidal zones of Jeju Island, including Pseudopolyneura hyacinthia (J. C. Kang \& M. S. Kim) M. J. Wynne (as Erythroglossum hyacinthinum, Kang and Kim 2014) and Pachymeniopsis volvita M. Y. Yang \& M. S. Kim (Yang and Kim 2015). Although Jeju Island has the potential to be named a seaweed genetic and species diversity hotspot (Yang et al. 2020), our knowledge of green seaweeds in subtidal zones remains poor. A few new ulvacean species have been reported in Hawaii and Japan, including U. oiohilulu, Um. kaloakulau, and R. kuaweuweu collected from the mesophotic zone, at depths of 30-125 m (Spalding et al. 2016, Kawai et al. 2020). Continuous surveys of green algae in the subtidal zone contribute to the expansion of ecological knowledge, which is essential for habitat conservation and species diversity enrichment. Therefore, we further emphasize the necessity of investigating green macroalgal diversity in the mesophotic zone to discover new species of the ulvaceaen genera Ulva, Umbraulva, and Ryuguphycus.

\section{ACKNOWLEDGEMENTS}

We thank Dr. Kang, J. C. and members of the Molecular Phylogeny of Marine Algae Laboratory at Jeju National University for helping us to collect samples. This study was supported by the 2020 Education, Research and Student guidance grant funded by Jeju National University.

\section{SUPPLEMENTARY MATERIALS}

Supplementary Table S1. The representative sequence datasets of Umbraulva and Ulva from GenBank including outgroups (https://e-algae.org). 


\section{REFERENCES}

Bae, E. H. \& Lee, I. K. 2001. Umbraulva, a new genus based on Ulva japonica (Holmes) Papenfuss (Ulvaceae, Chlorophyta). Algae 16:217-231.

Burrows, E. M. 1991. Seaweeds of the British Isles. Vol. 2. Chlorophyta. National History Museum Publications, London, pp. 238.

Chandler, C. J., Wilts, B. D., Brodie, J. \& Vignolini, S. 2017. Structural color in marine algae. Adv. Opt. Mater. 5:1600646.

Guiry, M. D. \& Guiry, G. M. 2020. AlgaeBase. World-wide electronic publication, National University of Ireland, Galway. Available from: http://www.algaebase.org. Accessed Jul 30, 2020.

Hall, T. A. 1999. BioEdit: a user-friendly biological sequence alignment editor and analysis program for Windows 95/98/NT. Nucleic Acids Symp. Ser. 41:95-98.

Heesch, S., Broom, J. E. S., Neill, K. F., Farr, T. J., Dalen, J. L. \& Nelson, W. A. 2009. Ulva, Umbraulva and Gemina: genetic survey of New Zealand taxa reveals diversity and introduced species. Eur. J. Phycol. 44:143-154.

Hoeksema, B. W. \& van den Hoek, C. 1983. The taxonomy of Ulva (Chlorophyceae) from the coastal region of Roscoff (Brittany, France). Bot. Mar. 26:65-86.

Kang, J. C. \& Kim, M. S. 2014. New red algal species, Erythroglossum hyacinthinum (Delesseriaceae, Rhodophyta) from Korea. Algae 29:1-13.

Kawai, H., Hanyuda, T., Mine, I., Takaichi, S., Terada, R. \& Kitayama, T. 2020. Morphology and molecular phylogeny of Umbraulva spp. (Ulvales, Ulvophyceae), and proposal of Ryuguphycus gen. nov. and R. kuaweuweu comb. nov. Eur. J. Phycol. Advanced online publication. htpps://doi.org/10.1080/09670262.2020.1753815.

Kirkendale, L., Saunders, G. W. \& Winberg, P. 2013. A molecular survey of Ulva (Chlorophyta) in temperate Australia reveals enhanced levels of cosmopolitanism. J. Phycol. 49:69-81.

Lee, H. W. \& Kim, M. S. 2015. Species delimitation in the green algal genus Codium (Bryopsidales) from Korea using DNA barcoding. Acta Oceanol. Sin. 34:114-124.

Lee, H. W. \& Kim, M. S. 2017. Palmophyllum crassum, a new record of an ancient species in green algae from Korea. Korean J. Environ. Biol. 35:319-328.
Manhart, J. R. 1994. Phylogenetic analysis of green plant $r b c \mathrm{~L}$ sequences. Mol. Phylogenet. Evol. 3:114-127.

Medlin, L., Elwood, H. J., Stickel, S. \& Sogin, M. L. 1988. The characterization of enzymatically amplified eukaryotic 16S-like rRNA-coding regions. Gene 71:491-499.

National Institute of Biological Resources. 2019. National species list of Korea. I. Plants, fungi, algae, prokaryotes. National Institute of Biological Resources, Incheon, 924 pp.

Rambaut, A. 2012. FigTree, tree figure drawing tool v1.4.0. Institute of Evolutionary Biology, University of Edinburgh. Available from: http://tree.bio.ed.ac.uk/software/figtree/. Accessed May 30, 2018.

Saunders, G. W. \& Kucera, H. 2010. An evaluation of $r b c \mathrm{~L}$, tufA, UPA, LSU and ITS as DNA barcode markers for the marine green macroalgae. Cryptogam. Algol. 31:487528.

Spalding, H. L., Conklin, K. Y., Smith, C. M., O’Kelly, C. J. \& Sherwood, A. R. 2016. New Ulvaceae (Ulvophyceae, Chlorophyta) from mesophotic ecosystems across the Hawaiian Archipelago. J. Phycol. 52:40-53.

Stamatakis, A. 2006. RAxML-VI-HPC: maximum likelihoodbased phylogenetic analyses with thousands of taxa and mixed models. Bioinformatics 22:2688-2690.

Tamura, K., Peterson, D., Peterson, N., Stecher, G., Nei, M. \& Kumar, S. 2011. MEGA5: Molecular evolutionary genetic analysis using maximum likelihood, evolutionary distance, and maximum parsimony methods. Mol. Biol. Evol. 28:2731-2739.

Tanaka, T. 1956. Studies on some marine algae from southern Japan, II. Mem. Fac. Fish. Kagoshima Univ. 5:103108.

Yang, M. Y. \& Kim, M. S. 2015. Taxonomy of Grateloupia (Halymeniales, Rhodophyta) by DNA barcode marker analysis and a description of Pachymeniopsis volvita sp. nov. J. Appl. Phycol. 27:1373-1384.

Yang, M. Y., Yang, E. C. \& Kim, M. S. 2020. Genetic diversity hotspot of the amphi-Pacific macroalga Gloiopeltis furcata sensu lato (Gigartinales, Florideophyceae). J. Appl. Phycol. 32:2515-2522.

Yokohama, Y. 1981. Distribution of the green light-absorbing pigments siphonoxanthin and siphonein in marine green algae. Bot. Mar. 24:637-640. 